\title{
Kronik İshalin Nadir Bir Sebebi: Eozinofilik Kolit
}

\author{
Muhammed Sait Dağ
}

DOI: $10.17944 /$ mkutfd.790823

Muhammed Sait Dağ: Uzm. Dr. Medical Park Gaziantep Hastanesi, Gastroenteroloji Kliniği, Gaziantep

Email: drmsait@windowslive.com

ORCID iD: https://orcid.org/0000-0003-0033-8151

Bildirimler/Acknowledgement

* Sorumlu Yazar/Corresponding Author

Çıkar Çatıșması/Conflict of Interest

Yazarlar bu makale ile ilgili herhangi bir çıkar

çatıșması bildirmemișlerdir.

The authors declare that they have no conflict of

interests regarding content of this article.

Maddi Destek/Financial Support

Yazarlar bu makale ile ilgili herhangi bir finansal

destek bildirmemișlerdir.

The Authors report no financial support regarding content of this article.

\section{Etik Beyan/Ethical Declaration}

Yazarlar, çalıșma için Sanko Üniversitesi Klinik Araștırmalar Etik Kurulundan 13.08.2020 tarih ve 2020/14 karar sayı ile izin alındığını, çalıșmanın yürütülmesi esnasında Helsinki Beyannamesi 2013, ICJM tavsiyeleri ile COPE'un Editör ve Yazarlar için Uluslararası Standartlarının yanısırailgili diğer biyoetik kılavuzların dikkate alındığını beyan etmişlerdir.

Permission was obtained from the Sanko University, Clinical Research Ethics Committee for this study with date 13.08.2020 and number 2020/14, and Helsinki Declaration rules were followed to conduct this study.

Geliș/Received: 05.09 .2020

Düzeltme/Revised: 13.09 .2020

Kabul/Accepted: 19.09.2020

e-ISSN: 2149-3103

Web: http://dergipark.org.tr/mkutfd 0̈z

Kronik Ishalin Nadir Bir Sebebi: Eozinofilik Kolit

Amaç: Eozinofilik kolit kronik ishalin nadir ancak hayat kalitesi üzerine uzun süreli olumsuz etkileri nedeniyle önemli bir sebebidir. Ülkemizden eozinofilik kolit ile ilgili yayınlar sınırlı olup, bu yazıda kliniğimizin bu konudaki verilerinin paylașılması amaçlanmıștır.

Gereç ve Yöntem: Çalıșmaya Mayıs 2016 ve Haziran 2020 tarihleri arasında kronik ishal etiyolojisi araștırılmak üzere kolonoskopi yapılan ve patolojik inceleme sonucu eozinofilik kolit tanısı konan vakalar dahil edildi. Hastaların demografik özellikleri, klinik özellikleri, laboratuvar değerleri, kolonoskopik ve patolojik verileri retrospektif olarak incelendi.

Bulgular: Çalıșmaya 22 erkek ve 14 kadın olmak üzere toplam 36 vaka dahil edildi. Erkeklerin yaș ortalaması 42.6 (23-67) ve kadınların yaș ortalaması 52.2 yıl (18-75) idi. Bașlıca klinik bașvuru sebepleri ishal, karın ağrısı ve rektal kanama idi. Tanı öncesi șikâyet süresi ortalama 13,7 ay (2-48) ve tanı sonrası ortalama takip süresi 16.5 ay (2-49) idi. Periferik eozinofili 7/36 vakada saptandı. Tüm hastalara metilprednisolon 16-32 mg/gün dozunda verildi.

Sonuç: Eozinofilik kolit kronik ishalin hayat kalitesini etkileyen önemli bir sebebidir. Metilprednisolon tedavisi son derece etkili ve güvenlidir. Klinik șüphe ve kolonoskopik biyopsilerin histopatolojik incelenmesi tanı için en önemli faktörlerdir.

Anahtar Kelimeler: Kronik İshal, Kolit, Eozinofilik İnfiltrasyon

\section{Abstract}

A Rare Cause of Chronic Diarrhea: Eosinophilic Colitis

objective: Eosinophilic colitis, which is rare but has adverse effects on the quality of life, is an important reason for chronic diarrhea. However, there is limited publishing related to eosinophilic colitis in our country and here we aim to share our clinic's data on this issue.

Material and Method: The subjects, who had colonoscopy and were diagnosed with eosinophilic colitis with reference to pathological examination, were included to the study to analyze the chronic diarrhea aetiology between May 2016 and June 2020. Demographic qualifications, clinical features, laboratory results, colonoscopy and pathological data of the patients have been studied in as retrospectively.

Results: Totally 36 subjects including 22 men and 14 women, were involved into the study. The age average of men was 42.6 (23 to 67 ages) and the age average of women was 52.2 (18 to 75 ages). The main clinical application reasons were diarrhea, abdominal pain and rectal bleeding. The complaint period before diagnosis is 13.7 months (2 to 48 ) and the follow-up period after diagnosis is 16.5 months (2 to 49). The peripheral eosinophilia was detected with 7 out 36 cases. Methylprednisolone was administrated by patients as 16 to $32 \mathrm{mg} /$ day as a dosage.

Conclusion: The eosinophilic colitis is an important cause of chronic diarrhea that affects the quality of life. Methylprednisolone treatment is extremely efficient and safe. The clinical suspicion and examination of colonoscopy biopsy are important factors for diagnosis.

Keywords: Chronic Diarrhea, Colitis, Eosinophilic Infiltration

\section{GİRIŞ}

Günde 3 veya daha fazla sulu dışkılama ve 4 haftadan uzun süren klinik şikayetlerin olması kronik ishal olarak tanımlanır (1). İnflamatuvar bağırsak hastalıkları, bazı ilaçlar, bakterial, paraziter, viral enfeksiyonlar, irritabl bağırsak sendromu, malabsorbsiyon sendromları, mikroskopik kolitler, eozinofilik gastroenteritler kronik ishalin önemli sebepleridir $(1,2)$.

Eozinofilik gastrointestinal hastalıklar, eozinofilik gastroenterit, eozinofilik özofajit ve eozinofilik kolit (EK) olarak sınıflandırılabilir. Kolon duvarının mukozadan serozaya kadar değişik derecelerde eozinofiller tarafından infiltrasyonu ile karakterize EK, kronik ishalin nadir ve önemli bir sebebidir $(3,4)$. Hastalığın etyopatogenezi kesin olarak bilinmemekle beraber genetik ve çevresel etkenlerin beraber rol oynadığı düşünülmektedir (5). Eozinofiller gastrointestinal sistemde özefagus dışındaki tüm or- 
ganların lamina propriasında görülebilirler. En fazla çekum ve apendikste yerleşmişlerdir $(6,7)$.

Hastaların hayat kalitelerinde uzun süreli bozulmalara yol açması nedeniyle EK'in tanı ve tedavisi oldukça önemlidir. Bu yazıda EK ile ilgili ülkemiz verilerinin son derece sınırlı ve genellikle vaka sunumları $(8,9)$ şeklinde olmasından dolayı kliniğimizin bu konudaki verilerinin paylaşıması amaçlanmıştır.

\section{GEREÇ VE YÖNTEM}

Çalıșmaya Mayıs 2016 ve Haziran 2020 tarihleri arasında kronik ishal etiyolojisi araştırılmak üzere kolonoskopi yapılan ve histopatolojik olarak EK tanısı konan 36 vaka dahil edildi. Hastaların demografik özellikleri, klinik özellikleri, laboratuvar değerleri, kolonoskopik ve patolojik verileri retrospektif olarak incelendi. Gaita analizi ve amip incelemesi tüm vakalarda yapılmış olup, negatif olanlar çalışmaya dahil edildi. Çalışmaya dahil edilen tüm hastalarda çölyak hastalığının varlığı Doku transglutaminaz IgA serolojisi ve endoskopik olarak ekarte edilerek negatif olan hastalar çalışmaya dahil edildi. İnflamatuvar bağırsak hastalıkları, irritabl bağırsak hastalığı, malabsorbsiyon sendromları gibi kronik ishalin diğer sebepleri ile bilinen gida allerjisi, enfeksiyöz ishaller ve yakın tarihli bitkisel ya da ilaç kullanım öyküsü olan hastalar çalıșma dıșı bırakıldı. Çalıșmada tüm hastalarda kolonoskopik incelemede terminal ileum entübasyonu yapıldı ve sadece makroskopik olarak normal ileal endoskopik görünümü olanlar dahil edildi.

\section{Etik Beyan}

Bu çalışma için Sanko Üniversitesi Klinik Araştırmalar Etik Kurulundan 13.08.2020 tarih ve 2020/14 sayılı yazı ile izin alınmış olup Helsinki Bildirgesi kriterleri göz önünde bulundurulmuştur.

\section{BULGULAR}

Çalışmaya 22 erkek ve 14 kadın olmak üzere toplam 36 vaka dahil edildi. Erkeklerin yaş ortalaması 42.6 (23-67) ve kadınların yaş ortalaması 52.2 yıl (18-75) idi. Eşlik eden hastalık olarak 6/36 vakada diabetes mellitus, 5/36 vakada kolesistektomi ve 5/36 vakada koroner kalp hastalığ saptandı. Tüm vakalarda ishal majör klinik prezantasyon iken, 28/36 vakada karın ağrısı ve 5/36 vakada rektal kanama vardı. Günlük ishal sayısı 3-20 arasında değişmekteydi. Tanı öncesi şikâyet süresi ortalama 13,7 ay (2-48) ve tanı sonrası ortalama takip süresi 16.5 ay (2-49) idi. Periferik eozinofili 7/36 vakada ve Ig E yüksekliği 1/8 vakada saptandı. Tüm hastalarda terminal ileum entübasyonu yapıldı. Kolonoskopide 10/36 vakada değişik şiddette makroskopik eroz- yon ve kolit bulguları varken, diğer vakalarda mukozal yapı tamamen normaldi. Vakaların 7/36'sında değişik sayı ve büyüklükte polipler saptandı. Hastaların 5/36'sında daha önce yapılmış kolonoskopi öyküsü vardı. Tüm hastalara metilprednisolon $16-32 \mathrm{mg} /$ gün dozunda verildi. $31 / 36$ vakada 16 mg ve 5/36 vakada 32 mg' lik dozlar 4-6 haftada azaltılarak kesildi. Vakaların 7/36'sında 2. defa ve 1/36'sında 3. defa nüks eden ishal atakları nedeniyle medikal tedavi tekrarlandı ve tüm vakalarda remisyon sağlandı. Başka bir immunsupresif ajan ihtiyacı olmadı. Kolonoskopi ya da steroid tedavi ilişkili herhangi bir komplikasyon olmadı. Sadece 4 vakada hafif akneiform lezyon saptandı.

\section{TARTIŞMA}

Eozinofilik kolit prevalansı ile ilgili çalışmalar sınırlıdır. Hastalığın gerçek sıklığı bilinmemektedir. Değişik çalışmalarda prevalans yaklaşık 3/100000 olarak bildirilmiştir. Kronik ishal için yapılan kolonoskopik biyopsilerde ise tanı oranı \%0.1 olarak bildirilmiştir $(10,11)$. Ülkemizde EK prevalansı ile ilgili net bir veriye rastlanamamış olup kliniğimizde kronik ishal etiyoloji araştırılmak üzere yapılan kolonoskopik biyopsilerde EK sıklığı \%1.6 olarak saptanmıştır. Bu farklılık kendi toplumumuzda daha fazla vakanın olması yanı sıra alınan biyopsilerin yeri, sayısı, endoskopistin tecrübesi ve patologun farkındalığı gibi sebeplere bağlı da olabilir. Nadir bir hastalık olmasına rağmen tanı konmasındaki zorluk ve genellikle tanı öncesi hayat kalitesini önemli şekilde bozan uzun bir klinik rahatsızlı süresi olması, erken tanıyı değerli kılmaktadır (12). Bu çalışmada bu süre 13.7 ay olarak hesaplanmıştır. Farkındalık ve klinik tecrübenin olmadığı durumlarda hastalar nonspesifik ön tanı ve tedavilerle gereksiz şekilde zaman kaybetmektedirler.

Kolon duvarının eozinofilden zengin inflamatuvar hücrelerle infiltrasyonu sonucu gelişen EK'in primer kolonik eozinofiliden farkı hastaların semptomatik olmasıdır (13). Semptomlar genelde uzun süreli ve tekrarlayıcıdır. Hastalığın spesifik klinik bulgusu olmayıp, klinik tutulan tabakaya ve eozinofilik infiltrasyonun derecesine bağlı olarak çeşitlilik gösterir. En sık başvuru sebepleri ishal ve karın ağrısıdır $(6,7,13)$. Bu çalışmada hastaların tümünde ishal başlıca klinik yakınma iken, 2. sıklıkta genellikle kramp şeklinde olan karın ağrısı vardı. Sol kolonda endoskopik olarak kolit ya da erozyon saptanan 5 vakada ek klinik prezantasyon olarak rektal kanamada görülmüştür. Literatürde de alt GİS kanaması ya da kanlı ishal şeklinde olgu sunumları bildirilmiştir $(8,14)$.

Hastalığa özgü spesifik laboratuvar bulgusunun olmaması tanıyı zorlaştırmaktadır. Akut faz yanıtlarında ılımlı yükseklikler olduğu bildirilse de tanı açısından yol gösterici değildir. Değişik çalışmalarda periferik eozinofili varlığı farklı sıklıkta bildirilmiş olup, tüm vakalarda görülmemek- 
tedir $(6,7,15)$. Bu çalışmada vakaların yalnızca \%19.4' ünde periferik eozinofili saptanmıştır.

Kolonoskopik incelemede makroskopik mukozal görünüm genelde normaldir. Nadiren erozyon, ülser ya da nonspesifik kolit görünümü vardır $(15,16)$. Bu çalıșmada 10 vakada makroskopik anormallikler ve 7 vakada değişik sayı ve büyüklükte polipler saptanmıştır.

Hastalığın tanısı için en önemli adım EK'in hatırlanması ve alınan kolonoskopik biyopsilerin histopatolojik olarak incelenmesidir (17). Sekonder bir eozinofili varlığının olmadığı durumda biyopsi örneklerinin patolojik incelenmesinde bir büyük büyütme alanında 20 ve daha fazla eozinofil varlığı tanı için yeterlidir $(1,15,16)$. Çalıșmadaki vakalarda eozinofil sayısı 40-100 arası raporlanmıştır. Endoskopist ve patologun iş birliği tanıda en önemli parametredir.

Eozinofilik gastrointestinal hastalıklar ve EK tedavisinde lökotrien inhibitörleri, mast hücre stabilitörleri, IL-5 inhibitörleri ve anti-immünglobülin $\mathrm{E}$ ajanların etkinlikleri bildirilmiş olsa da başlıca ve etkin tedavi ajanı steroidlerdir $(3,13,15,16,18)$. Çalışmadaki tüm hastalarda metilprednisolon orta dozda 4-6 haftalık sürelerde etkin şekilde kullanılmış ve tüm vakalarda klinik remisyon sağlanmıştır. Vakaların hiçbirinde ciddi bir yan etki görülmemiştir.

$\mathrm{Bu}$ çalıșma sonucunda; EK kronik ishalin nadir ancak hayat kalitesini etkileyen önemli bir sebebidir. Hastalığa tanı koydurucu spesifik klinik, laboratuvar ya da endoskopik bulgu yoktur. Metilprednisolon tedavisi son derece etkili ve güvenlidir. Tanıda altın standart klinik șüphe ve kolonoskopik biyopsilerin histopatolojik incelenmesidir.

\section{KAYNAKLAR}

1. Yüksel ES, Topal F. Kronik diyare nedenleri. Güncel Gastroenteroloji 2017;21(2):101-7.

2. Headstrom PD, Surawicz CM. Chronic diarrhea. Clin Gastro Hep 2005;3:734-7. https://doi.org/10.1016/S1542-3565(05)00298-3

3. Vikas U, Portia K, Erika K. Eozinophilic gastroenteritis and colitis: a comprehensive review. Clin Rev Allergy Immunol 2016;50(2):17588. https://doi.org/10.1007/s12016-015-8489-4

4. Kuzu UB, Köksal AŞ. Eozinofilik gastrointestinal hastalıklar. Güncel Gastroenteroloji 2014;18(3):342-51.

5. Weshil BK, Walker A. The mucosal barrier, Ig E mediated gastrointestinal events and eozinophilic gastroenteritis. Gastroent Clin North Am 1992;21:387-404.
6. Khan S. Eozinophilic gastroenteritis. Best Pract Res Clin Gastroenterol 2005;19:177-98. https://doi.org/10.1016/j. bpg.2005.01.009

7. Rothenberg ME. Eozinophilic gastrointestinal disorders. J Allergy Clin Immunol 2004;113:11-28. https://doi.org/10.1016/j. jaci.2003.10.047

8. Ertuğrul I, Ulker A, Turhan N, Dağli U, Saşmaz N. Eozinophilic colitis as an unusual cause of severe bloody diarrhea. Turk J Gastroenterol 2008;19(1):54-6.

9. Kefeli A, Akturk A, Başyiğit S. Eozinophilic colitis complicated with renal infarction. Am J Emerg Med 2015;33(11):1703-4. https://doi. org/10.1016/j.ajem.2015.07.084

10. Walker MM , Potter MD, Talley NJ. Eozinophilic colitis and colonic eozinophilia. Curr Opin Gastroenterol 2019;35(1):42-50. https:// doi.org/10.1097/MOG.0000000000000492

11. Jensen ET, Martin CF , Kappelman MD, Dellon ES. Prevalence of eozinophilic gastritis, gastroenteritis, and colitis: estimates from a national administrative database. J Pediatr Gastroenterol Nutr 2016;62(1):36-42. https://doi.org/10.1097/ MPG.0000000000000865

12. Talley NJ, Shorter RG, Phillips SF, Zinsmeister AR. Eozinophilic gastroenteritis: a clinicopathological study of patients with disease of the mucosa, musclelayer and subserosal tissues. Gut 1990;31:548. https://doi.org/10.1136/gut.31.1.54

13. Impellizzeri G, Marasco G, Eusebi LH, Salfi N, Bazzoli F, Zagari RM. Eozinophilic colitis: a clinical review. Dig Liver Dis 2019;51(6):76973. https://doi.org/10.1016/j.dld.2019.04.011

14. Koçak G, Koçak E, Akbal E, Şen H, Erbağ G, Erdoğan C. Eozinophilic colitis: a rare cause of lower gastrointestinal bleeding in an elderly adult. J Am Geriatr Soc 2014;62(10):2016-7. https://doi. org/10.1111/jgs.13043

15. Tien FM, Wu JF, Jeng YM, Hsu HY, Ni YH, Chang MH, et al. Clinical features and treatment responses of children with eozinophilic gastroenteritis. Pediatr Neonatol 2011;52:272-8. https://doi. org/10.1016/j.pedneo.2011.06.006

16. Del Arco CD, Taxonera C, Olivares D, Aceñero MF . Eozinophilic colitis: case series and literature review. Pathol Res Pract 2018;214(1):100-4. https://doi.org/10.1016/j.prp.2017.09.029

17. Alfadda AA, Storr MA, Shaffer EA. Eozinophilic colitis: an update on pathophysiology and treatment. Br Med Bull 2011;100:59-72. https://doi.org/10.1093/bmb/ldr045

18. Okpara N, Aswad B, Baffy G. Eozinophilic colitis. World J Gastroenterol 2009;28:15(24):2975-9. https://doi.org/10.3748/ wjg.15.2975 